УдК 343.98:343.4

\author{
О. В. Таран, С. С. Чернявський
}

\title{
ПРОБЛЕМИ МЕТОДИКИ РОЗСЛІДУВАННЯ ЗЛОЧИНІВ ПРОТИ БЕЗПЕКИ ВИРОБНИЦТВА
}

Постановка проблеми. Одним із пріоритетів розвитку України як демократичної правової держави, що керується європейськими політичними й економічними цінностями, визнано створення безпечних і здорових умов праці людини в процесі трудової діяльності. Запобігання нещасним випадкам, травматизму і професійним захворюванням, модернізація основних фондів і технологій, потенційно небезпечних для життя та здоров'я працівників, визнаються напрямами реалізації внутрішньої політики, що узгоджується із закріпленими в конвенціях Міжнародної організації праці й директивах Європейського Союзу принципами захисту прав людини.

Мета статті - визначити перспективні напрями вдосконалення методики розслідування злочинів проти безпеки виробництва.

Виклад основного матеріалу дослідження. Сталі тенденції в країні до збільшення кількості виявлених випадків виробничого травматизму, прагнення роботодавців отримувати більші прибутки за рахунок ігнорування (а нерідко й свідомого порушення) вимог законодавства про охорону праці й нехтування правилами техніки безпеки (питома вага підприємств із незадовільними умовами праці та зношеними виробничими фондами становить 55\%) є чинниками, які протягом багатьох років призводять до значних людських жертв і масштабних руйнувань. Такі суспільно небезпечні наслідки викликають занепокоєння органів державної влади й негативну реакцію з боку громадськості та зарубіжних експертів.

Поширеною залишається практика приховування від офіційного розслідування нещасних випадків на виробництві. Про це, зокрема, свідчить показник кількості нещасних випадків на виробництві в загальній динаміці. В Україні він у середньому становить 10 на 100, тоді як у країнах Європи, наприклад, він коливається від 100 до 1000, а кількість щорічно виявлених професійних захворювань практично в три раз перевищує аналогічний показник в Україні, і це при тому, що загалом умови праці в цих країнах об'єктивно кращі. Наведені цифри характеризують загальний технологічний і організаційний рівень виробництва в Україні, ставлення державних і приватних власників до питань охорони праці та здоров'я працівників.

Таран О. В., Чернявський С. С., 2017 
Аналіз статистичних даних щодо кількості кримінальних проваджень (злочини, передбачені ст. ст. 271-275 Кримінального кодексу (далі - KK) України) та зіставлення їх із показниками державних органів нагляду й контролю за дотриманням вимог законодавства про охорону праці (кількість нещасних випадків у т. ч. зі смертельними наслідками) дають підстави для висновку про неналежне реагування правоохоронних органів на злочини проти безпеки виробництва.

За різними оцінками, майже дві третини кримінальних правопорушень, відповідальність за які передбачена ст. ст. 271-275 КК України, приховують від реєстрації, а винні в них службові особи здебільшого уникають відповідного реагування з боку правоохоронних органів і кримінальної відповідальності.

Вивчення правозастосовної практики свідчить, що вже на початковому етапі досудового розслідування виникають значні ускладнення під час збирання доказів, пов'язані з відсутністю у слідчих відповідного професійного досвіду, незнанням ними положень регулятивного законодавства 3 питань охорони праці й техніки безпеки, недосконалістю окремих положень методики розслідування. Відомі ситуації активної протидії слідству з боку службових осіб, які відповідали за створення належних умов праці, шляхом приховування й фальсифікації інформації про нещасні випадки, перешкоджання проведенню кваліфікованих перевірок за фактами аварій, використання корупційних та інших важелів для тиску на потерпілих, свідків [1].

Викладене в загальних рисах формує уявлення про особливості й умови вчинення злочинів проти безпеки виробництва, що необхідно для визначення специфіки їх розслідування.

Підвищенню ефективності розслідування злочинів проти безпеки виробництва має сприяти системне й послідовне розроблення та впровадження в практичну діяльність сучасних криміналістичних методик, які враховують досвід і потреби правозастосовної практики, містять криміналістичний аналіз специфічної нормативно-правової бази, відображають специфіку відомчого (міжвідомчого) організаційного забезпечення, що передбачає необхідність установлення специфічних ознак з урахуванням норм інших галузей права, відображають криміналістично значущі особливості їх учинення та розслідування [2].

Проблеми методики розслідування злочинів, що порушують безпечні умови праці, розглядали Ш.К. Вахітов, В.К. Глістін, М.С. Грінберг, В.І. Жирютін, С.А. Квелідзе, П.В. Кобзаренко, М.П. Яблоков та ін.

Констатуючи безперечний вагомий внесок цих учених у розроблення зазначеної проблеми, зауважимо, що їхні наукові пошуки торкалися лише окремих аспектів, актуальних на певних етапах розвитку законодавства та правоохоронної практики. А тому окремі положення вимагають додаткового, більш детального аналізу й розгляду з урахуванням сучасного стану законодавства та соціально-економічного розвитку країни.

Ідеться про доцільність розроблення методик розслідування окремих видів (груп) злочинів, а також спеціальних методик [3]. 
Це зумовлено тим, що злочини проти безпеки виробництва часто характеризуються особливостями, які проблематично передбачити й належним чином відобразити в рамках єдиної методики розслідування.

Наприклад, розслідування таких злочинів, скоєних на малих підприємствах, вимагає врахування низки особливостей, пов'язаних із нормативно-правовою регламентацією діяльності цих підприємств, специфіки корпоративної етики (культури), які нерідко визначають криміналістичну характеристику особи потерпілого і злочинця, а іноді й спосіб учинення злочину.

Матиме свою специфіку й розслідування злочинних порушень правил охорони праці й техніки безпеки залежно від галузі виробництва: вугільна, нафтогазовидобувна, енергетика, будівництво, машинобудування, хімічна, газова тощо [4].

Водночас немає необхідності й у зайвій деталізації таких методик, оскільки це призведе до дублювання багатьох їх положень, а властива їм специфіка буде втрачена. На нашу думку, універсальним можна вважати раніше згаданий підхід.

Нині вже здійснено наукові спроби подальшого розвитку й удосконалення базових положень методики розслідування злочинів проти безпеки виробництва, розроблено та впроваджено в практичну діяльність відповідні методичні рекомендації, що свідчить про теоретичне і практичне значення таких досліджень.

Запропоновано таку систему методик розслідування злочинів, передбачених ст. ст. 271-275 КК України:

- загальна (базова) методика розслідування (основні ії положення загалом розроблені О.В. Таран);

- методики розслідування окремих видів (груп) злочинів: за галузевою ознакою (сферами виробництва, організаційно-правовими формами підприємств); за характером порушених правил охорони праці (загальних і спеціальних для окремих видів виробничої діяльності) (положення методики розслідування правил безпеки під час виконання робіт із підвищеною небезпекою розкрито в роботах М.Я. Панчишина [5], К.О. Спасенка);

- спеціальні методики, сформовані за видовою, внутрішньовидовою, позавидовою ознаками.

Науковий інтерес до цієї теми не випадковий, причини його були названі на початку статті, але наведеними фактами, звичайно, не вичерпані. Зростання обсягів виробництва, впровадження сучасних технологій, розвиток окремих галузей, підвищення професійного рівня працівників, зміни в законодавстві - все це й багато іншого визначало та буде визначати специфіку порушень правил охорони праці й техніки безпеки, а також впливати на методику їх розслідування, що, у свою чергу, потребує своєчасного реагування наукового знання на потреби правозастосовної практики.

Висновки. Отже, подальший розвиток і вдосконалення методики розслідування злочинів проти безпеки виробництва $є$ необхідним і перспективним напрямом наукових криміналістичних досліджень. 


\section{Література}

1. Таран О.В. Криміналістичне забезпечення розслідування злочинів, пов'язаних з порушенням вимог законодавства про охорону праці : автореф. дис. ... докт. юрид. наук : 12.00 .09 «Кримінальний процес та криміналістика; судова експертиза; оперативно-розшукова діяльність». K., 2013. - 34 c.

2. Чернявский С.С. Вопросы организации расследования преступлений в системе криминалистических знаний / С.С. Чернявский / / Криміналістика та судова експертиза: наука, навчання, практика : зб. наук. праць 10 (позачергової) Міжнародної наук.-практ. конф. (м. Ужгород, 28-29 червня 2014 р.) : у 2 т. - Х., 2014. - Т. 1. - С. 489-495.

3. Мастерство раскрытия преступлений : [пособие] / [В.П. Бахин, С.С. Чернявський, В.В. Юсупов]. - К., $2014-94$ с.

4. Таран Е.В. К вопросу о формировании методики расследования преступлений против безопасности производства / Е.В. Таран // Борьба с преступностью: теория и практика : тезисы докладов IV Международной научно-практической конференции (Могилев, 25 марта 2016 года) / M-во внутр. дел Респ. Беларусь, учреждение образования «Могилевский институт Министерства внутренних дел Республики Беларусь» ; ред. кол.: Ю.П. Шкаплеров (отв. ред.) и др. - Могилев : Могилев. институт МВД, 2016. - С. 472-474.

5. Таран О.В. Розслідування порушень правил безпеки під час виконання робіт з підвищеною небезпекою : [методичні рекомендації] О.В. Таран, М.Я. Панчишин. - К., 2015. - 78 с.

\section{Ано т а ц}

Таран О. В., Чернявський С. С. Проблеми методики розслідування злочинів проти безпеки виробництва. - Стаття.

У статті визначено перспективні напрями вдосконалення методики розслідування злочинів проти безпеки виробництва. Запропоновано систему методик розслідування цих злочинів.

Ключові слова: криміналістична методика, злочини проти безпеки виробництва, розслідування, криміналістичні рекомендації.

\section{Анн о т а ция}

Таран E. B., Чернявский C. C. Проблемы методики расследования преступлений против безопасности производства. - Статья.

В статье определены перспективные направления совершенствования методики расследования преступлений против безопасности производства. Предложена система методик расследования этих преступлений.

Ключевые слова: криминалистическая методика, преступления против безопасности производства, расследования, криминалистические рекомендации.

\section{S u m m a r y}

Taran O. V., Chernyavsky S. S. Problems of methods of investigating crimes against the safety of production. - Article.

The article defines promising directions for improving the methodology for investigating crimes against the safety of production. A system of methods for investigating these crimes is proposed.

Key words: forensic methodology, crimes against the safety of production, investigation, forensic recommendations. 